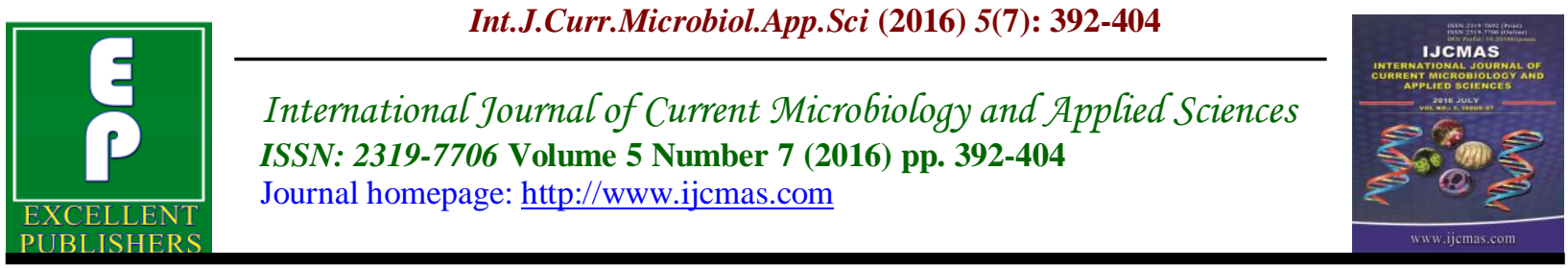

Original Research Article http://dx.doi.org/10.20546/ijcmas.2016.507.043

\title{
Phytoremediation of Heavy Metals by Helianthus annuus in Aquatic and Soil environment
}

\author{
M. H. Fulekar ${ }^{1,2 *}$ \\ ${ }^{1}$ School of Environment and Sustainable Development \\ Central University of Gujarat, Sector 30, Gandhinagar 382030 India \\ ${ }^{2}$ Environmental Biotechnology Laboratory, Department of Life Sciences \\ University of Mumbai, Vidyanagari, Santacruz (E) Mumbai 400098, India \\ *Corresponding author
}

\section{Keywords}

Phytoremediation, Helianthus annuus, heavy metals, potential, Aquatic and Soil environment.

\begin{tabular}{l} 
Article Info \\
\hline Accepted: \\
15 June 2016 \\
Available Online: \\
10 July 2016
\end{tabular}

\section{A B S T R A C T}

Phytoremediation that uses various types of plants to remove, transfer, stabilize and/or degrade contaminants from the soil-water environment is an emerging technology. This offers an attractive, environmental friendly, cost effective and safe alternative to conventional clean up techniques, by utilizing the ability of certain plant species to remediate metal polluted soil-water, thus keeping them out of the food chain. The present paper describes the potential of Helianthus annuus for remediation of heavy metals such as cadmium, lead and zinc from aquatic and mycorrhizal soil environment. Phytoremediation of heavy metals by $H$. annuus shows that the plants have remediated $79-90 \% \mathrm{Cd}, 77-89 \% \mathrm{~Pb}$ and $81-92 \% \mathrm{Zn}$ at $5-50 \mathrm{ppm}$ concentrations from the aquatic environment. The metal accumulation efficiency of the plant increased with increasing metal concentration and exposure period. $H$. annuus has been found to have high biomass at varying exposure concentrations which resulted in increased uptake of heavy metals. Maximum levels of zinc, cadmium and lead were observed in roots followed by shoots. A pot culture experiment was carried out to study the uptake of heavy metals, in particular $\mathrm{Cd}, \mathrm{Pb}$ and $\mathrm{Zn}$ from mycorrhizal soil by $H$. annuus. The uptake and bioaccumulation of metals was increased as the concentrations of the metals increased in mycorrhizal soil. The bioaccumulation of metals in roots was increased upto 35,600 $\mu \mathrm{g} \mathrm{gm}^{-1}-\mathrm{Cd}, 32,473 \mu \mathrm{g} \mathrm{gm}^{-1}-\mathrm{Pb}$ and 34,535 $\mu \mathrm{g} \mathrm{gm}^{-1}-\mathrm{Zn}$; whereas uptake in shoots was found $8,194 \mu \mathrm{g} \mathrm{gm}^{-1} \mathrm{Cd}, 16,227 \mu \mathrm{gm}^{-1} \mathrm{~Pb}$ and $19,040 \mu \mathrm{g} \mathrm{gm}^{-1} \mathrm{Zn}$ at higher metal concentration (50 ppm). The accumulation of metals was recorded highest in roots of the plant followed by shoots. The result indicates that mycorrhizosphere has enhanced the growth and uptake potential of sunflower in respect of $\mathrm{Cd}, \mathrm{Pb}$ and $\mathrm{Zn}$ at varying concentrations viz. 5, 10, 20 and $50 \mathrm{ppm}$. The research findings have proved the potential of $H$. annuиs for remediation of metals from contaminated soil-water environment.

\section{Introduction}

Rapid industrialization, urbanization, deforestation, increased use of pesticides, chemical fertilizers in agriculture, and other developmental activities have resulted in depletion of natural resources, causing impact on ecosystems and degradation and deterioration of the environment. The accelerated growth of industrial activities has 
increased the hazardous wastes. The main sources of the hazardous contaminants are generated by the chemical industries, nuclear industries. Nuclear wastes generated through chemical processing and/or nuclear weapons program have also enhanced the level of hazardous environmental contaminants. The hazard of radioactive waste depends on the nature of radionuclides and, at the same concentration, different radionuclides have different levels of hazard. Radioactive wastes found to contain radionuclides (U, $\mathrm{Pu}, \mathrm{Tc}, \mathrm{Cs}, \mathrm{Sr})$, heavy metals $(\mathrm{Cr}, \mathrm{Pb}, \mathrm{Hg}$, $\mathrm{Zn}, \mathrm{Cd}$ ) and toxic organics (e.g. Benzene, Toluene, Ethylene, Xylene, Trichloroethylene, Tri butyl phosphate, Di butyl phosphate etc.). The conventional methods like physico-chemical treatments are not being practiced to decontaminate the radioactive wastes. Environmental management of the metals and radionuclides has become a major concern to the environmentalists. There is an urgent need to develop cost-effective and sustainable technology to remove/reduce contaminants from the environment. Phytoremediation technology uses green plants to reduce, remove, degrade or immobilize environmental pollutants/ toxins from soil, water with an aim of restoring area sites to a condition useable for intended use (Vidali, 2001). The effectiveness of phytoremediation technology depends on the selection of appropriate plants or plant species. Plants are unique organisms equipped with remarkable metabolic and adsorption capabilities, as well as transport systems that can take up nutrients or contaminants selectively from the soil and water. The present research study has been carried out to develop "Phytoremediation Technology" for nuclear waste contaminants with special reference to heavy metals. The techniques have been developed for removal of heavy metals- $\mathrm{Cd}, \mathrm{Pb}$ and $\mathrm{Zn}$ from aquatic and mycorrhizal soil environment. Green plants adapted in the environmental contaminated sites have been screened for their uptake potential at varying concentrations of heavy metals $(\mathrm{Cd}, \mathrm{Pb}$ and $\mathrm{Zn}$ ). Based on the uptake potential of heavy metals, the green plant was screened and selected- Helianthus annuus. These plants were used for phytoremediation of heavy metals both from aquatic and soil environment. Metals concentrations were taken ranging from $0,5,10,20$ and $50 \mathrm{ppm}$, based on the tolerance potential of screened and selected plants.

\section{Materials and Methods}

\section{Plant materials}

The seeds of Helianthus annuus L. (Sunflower var. TAS 82) were obtained from Punjabrao Krishi Vidyapeeth, Akola, Maharashtra. Seeds were pre-soaked in soap and dettol solution for 15 minutes and thoroughly washed in running tap water until the soap solution was completely removed. Then the seeds were sterilized with $70 \%$ ethanol for 30 seconds followed by sterilization with $0.1 \%$ mercuric chloride for 3-5 min. The seeds were thoroughly rinsed 5 times with sterile distilled water. These sterilized seeds were inoculated in test tubes containing MS (Murashige and Skoog 1962) basal medium supplemented with $3 \%$ sucrose. Seedlings were allowed to grow for one month under in vitro condition.

\section{Hydroponic Experimental setup}

Uniform plants were selected for the uptake study. MS medium was drained off and replaced with hydroponics media i.e. Hoagland solution (Hoagland and Arnon, 1938) containing nutrient solution for the acclimatization for 1 week prior to the experiment. They are then transferred to another Steinberg solution which contained 
each of the following heavy metal in a separate set up: Cadmium supplied as $\mathrm{Cd}$ $\left(\mathrm{NO}_{3}\right)_{2} .4 \mathrm{H}_{2} \mathrm{O}$; lead supplied as $\mathrm{Pb}\left(\mathrm{NO}_{3}\right)_{2}$; and zinc supplied as $\mathrm{ZnSO}_{4}$. The different concentrations of metals used in these studies were 5, 10, 20, and $50 \mathrm{ppm}$ with control. Each experiment was carried out in triplicates. Plants grown in nutrient solution without metals served as control. The sampling from aqueous solution containing metals has been carried at an interval of 0 , $1^{\text {st }}, 3^{\text {rd }} 7^{\text {th }}, 14^{\text {th }}$ and $21^{\text {st }}$ days in vitro condition to ensure that uptake of each metal is being taking place (Anamika et al. 2009). $500 \mu \mathrm{l}$ of aliquots were withdrawn from each concentration with increasing period. These samples were used for the analysis of cadmium, lead and zinc content. The reduction in concentration of these metals in the medium was attributed to their uptake by the plants. At the end of the experiment the plant samples were collected and washed with de-ionized water twice and rinsed with distilled water. Each sample was divided into root and shoot and oven-dried at $60^{\circ} \mathrm{C}$ until completely dry. Dry weights of roots and shoots were determined and noted.

\section{Soil sampling}

The alluvial soil used in the pot experiment, was collected from a depth of about $0-15 \mathrm{~cm}$ along the banks of Surya River, Palghar (located $100 \mathrm{~km}$ away from Mumbai). The soil was air-dried and then passed through 2 $\mathrm{mm}$ sieve, and large stones and plant root debris were removed. This prepared soil was stored in a plastic bag at room temperature $\left(27-30^{\circ} \mathrm{C}\right)$ until the use.

\section{Pot Culture Experiment}

Pot culture experiments were conducted in the green house. The growth medium in the pots consisted of alluvial soil and mycorrhizal inoculum (5:1) and treated as Mycorrhizal soil (MS). The alluvial soil without the mycorrhizal inoculum was treated as control. Mycorrhizal soil filled in each $1 \mathrm{Kg}$ capacity of pot (having perforated base for proper aeration and drain connecting system) and amended with heavy metals: $\mathrm{Cd}$ as $\mathrm{Cd}\left(\mathrm{NO}_{3}\right)_{2} \cdot 4 \mathrm{H}_{2} \mathrm{O} ; \mathrm{Pb}$ as $\mathrm{Pb}$ $\left(\mathrm{NO}_{3}\right)_{2}$ and $\mathrm{Zn}$ as $\mathrm{ZnSO}_{4}$, separately. The various concentrations applied for each heavy metal was; $0,5,10,20,50 \mathrm{mg} \mathrm{kg}^{-1}$.

The healthy Helianthus annuus seeds were surface-sterilized with $0.1 \%$ mercuric chloride for $5 \mathrm{~min}$ and subsequently washed several times with distilled water to avoid fungal contamination. Six seeds were sown into each pot and the pots were randomly placed in a green house at an average diurnal temperature of $25-27^{\circ} \mathrm{C}$, and a relative humidity $40-60 \%$. Plants were watered to maintain soil moisture at $60-70 \%$ of water holding capacity by adding water during the experiment. $100 \mathrm{ml}$ of Hoagland solution (Hoagland and Arnon, 1938) was given to growing plants once in a week. The drainage collected at the bottom of the pot was also added in the pots to avoid the loss of metals through leachate. The plants were grown for a period of two and half months.

\section{Analytical Methods}

Each sample (dried root and shoots) was digested with $10 \mathrm{ml}$ of perchloric acid: nitric acid $\left(\mathrm{HClO}_{4}: \mathrm{HNO}_{3}-1: 5 \mathrm{v} / \mathrm{v}\right)$ mixture separately. Acid digestion was carried out on hot plate at $70-100^{\circ} \mathrm{C}$ until yellow fumes of $\mathrm{HNO}_{3}$ and white fumes of $\mathrm{HClO}_{4}$ were evolved. The digestion process was continued until a clear solution remains after volatilization of acids. The digestion was stopped when the residue in the flask was clear and white. The digested sample was dissolved in distilled water, filtered for the removal of impurities (APHA, 1998) and made up to the desired volume. The samples were analyzed by GBC 932 B+ Atomic 
Absorption Spectrophotometer (Australia) using air-acetylene flame to estimate cadmium, lead and zinc contents in the plant samples.

\section{Data Analysis}

The heavy metals are taken up by the plants through their roots from the solution. Experimental data were analyzed for uptake of cadmium, lead and zinc by Indian mustard plants. The experiment was carried out in triplicates and average values are reported. Data were analyzed for mean and standard deviation (X \pm S.D.) using standard statistical methods (Mahajan, 1997).

\section{Results and Discussion}

\section{Phytoremediation of Heavy Metals in Aquatic Environment}

The remediation of heavy metals $(\mathrm{Cd}, \mathrm{Pb}$ and $\mathrm{Zn}$ ) was carried out using $H$. annuus from aquatic environment at the concentrations ranging from $0,5,10,20$ and $50 \mathrm{ppm}$ for a period of 21 days. The healthy plants of Sunflower were grown in Hoagland solution spiked with various concentrations of $\mathrm{Cd}, \mathrm{Pb}$ and $\mathrm{Zn}$, separately. After the growth, the plants were harvested and analyzed for biomass and metal uptake of heavy metals in the roots/ shoots.

\section{Depletion of metals from the solution}

The experiment was carried out for a period of 21 days and aliquots of $500 \mu \mathrm{l}$ were withdrawn from each plant growth medium at the interval of $0,1,3,7,14$ and 21 days. These samples were analyzed for cadmium, lead and zinc content, separately. The results show that $H$. annuus has efficiently taken each heavy metal from the solution (Fig. 1). $H$. annuus has remediated $79-90 \%$ of $\mathrm{Cd}$ (Fig. 1A), 77-89\% of $\mathrm{Pb}$ (Fig. 1B) and 81$92 \%$ of $\mathrm{Zn}$ (Fig. 1C) at 5-50 ppm concentrations from the aquatic environment. The highest amount of $\mathrm{Zn}$ was translocated from solution to the plant than $\mathrm{Pb}$ and $\mathrm{Cd}$. The metals studied showed that depletion of metal from aquatic environment was inversely proportional to increasing period of phytoremediation. $\mathrm{Zn}$ being a micronutrient was found proportionately bioaccumulated at lower to higher concentrations upto $50 \mathrm{ppm}$; whereas $\mathrm{Pb}$ and $\mathrm{Cd}$ was found toxic to the plants as the concentration increased from 20 to $50 \mathrm{ppm}$.

\section{Dry biomass analysis}

After 21 days of experiment, the biomass of $H$. annuus was determined with respect to each heavy metal (cadmium, lead and zinc). Table 1 represents the dried biomass of $H$. annuus for $\mathrm{Cd}, \mathrm{Pb}$ and $\mathrm{Zn}$. There were significant differences in the biomass of $H$. annuus, when exposed to $\mathrm{Cd}, \mathrm{Pb}$ and $\mathrm{Zn}$ at various concentrations ranging from minimum to $50 \mathrm{ppm}$. Biomass of plant was found to be $0.014 \mathrm{~g}$ in roots and $0.076 \mathrm{~g}$ in shoots for $\mathrm{Cd}, 0.021 \mathrm{~g}$ in roots and $0.222 \mathrm{~g}$ in shoots for $\mathrm{Pb}$ and $0.042 \mathrm{~g}$ in roots and 0.451 $\mathrm{g}$ in shoots for $\mathrm{Zn}$ at $50 \mathrm{ppm}$ exposure; after 21 days period. The biomass yield was reduced with increasing concentration of metals. The statistical analysis has been given for each heavy metal $(\mathrm{Cd}, \mathrm{Pb}$ and $\mathrm{Zn})$ for minimum to $50 \mathrm{ppm}$ exposure concentrations. The biomass was also inversely proportional to increasing period of metal exposure. Similar findings were reported by Boonyapookana et al. (2005), in which the plant biomass of $H$. annuus in $\mathrm{Pb}$ contaminated nutrient media declined with increasing concentration. Kayser et al. (2001) demonstrated that $H$. annuus produced the largest biomass as compared to B. juncea and $\mathrm{S}$. viminalis in $\mathrm{Zn}$ and $\mathrm{Cd}$ contaminated soil. Higher doses of heavy metal can affect physiology, reduced plant growth and dry biomass yield (Grifferty and Barrington, 2000; Roy et al., 2005). Result 
shows that $H$. annuus has tolerance potential to grow in contaminated environment and efficiently remediated heavy metals in aquatic conditions.

\section{Bioaccumulation of metals in the roots and shoots of plants}

Our study showed higher accumulation of all metals $(\mathrm{Cd}, \mathrm{Pb}$ and $\mathrm{Zn})$ in the roots than in the shoots. The results based on the statistical analysis showed an increasing trend as the concentration of heavy metals increased from 5, 10, 20 and $50 \mathrm{ppm}$. The accumulation of metal was found more in roots followed by the shoots of sunflower. The concentration of $\mathrm{Cd}$ in sunflower was found $29,550 \mu \mathrm{g} \mathrm{gm}^{-1}$ and $7,657 \mu \mathrm{g} \mathrm{gm}^{-1}$ in roots and shoots, respectively at the higher exposure concentration i.e. 50 ppm (Fig.2A). $\mathrm{Pb}$ concentration was found in roots 31,532

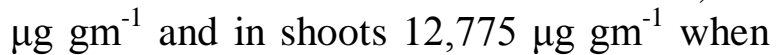
exposed to $50 \mathrm{ppm}$ of $\mathrm{Pb}$ (Fig.2B). The highest concentration of $\mathrm{Zn}$ exposure at 50 ppm shows the values for root- 33,325 $\mu \mathrm{g}$ $\mathrm{gm}^{-1}$ and shoot- 15,940 $\mu \mathrm{g} \mathrm{gm}^{-1}$ (Fig.2C). Each metal content was found bioaccumulated more in roots than the shoots as the roots first exploit the uptake of nutrients along with metal content and bioaccumulated in plant. $\mathrm{Pb}$ was found more bioaccumulated in roots as compared to other two metals studied ( $\mathrm{Cd}$ and $\mathrm{Zn}$ ). Results indicate that most of the $\mathrm{Cd}, \mathrm{Pb}$ and $\mathrm{Zn}$ concentrations were retained in the roots leading to less translocation to aerial part (Fig. 2). Roots of the plants act as a barrier against heavy metal translocation and this may be a potential tolerance mechanism operating in the roots (Ernst et al., 1992). These results are in agreement with the earlier reports on aquatic plants, which have shown significant accumulation of metal in the roots from the externally supplied metal solution (Sinha et al., 1996, 2002; Aslan et al., 2003). The effect of repeated metal exposure is also showing an increase in metal accumulation in treated plants as reported earlier by Sinha et al., 2002, 2003. The order of metal uptake by $H$. annuus was found $\mathrm{Cd}<\mathrm{Pb}<\mathrm{Zn}$. $\mathrm{Zn}$ being a micronutrient, was efficiently taken by the plants in higher concentrations as compared to the $\mathrm{Pb}$ and $\mathrm{Cd}$.

The heavy metals, viz. $\mathrm{Cd}, \mathrm{Pb}$ and $\mathrm{Zn}$ accumulation in roots and shoots of the plant- $H$. annuus was compared and shown Fig. 2. The data demonstrate that heavy metals studied were found accumulated more in roots followed by shoots of $H$. annuus. The metal uptake in roots was found 2,430 $\mu \mathrm{g} \mathrm{gm}{ }^{-1}(\mathrm{Cd}), 2,222 \mu \mathrm{g} \mathrm{gm}{ }^{-1}(\mathrm{~Pb})$ and 2,784 $\mu \mathrm{g} \mathrm{gm}^{-1}(\mathrm{Zn})$ at lower level of metals exposure $(5 \mathrm{ppm})$. The uptake of metals in roots was increased upto $29,550 \mu \mathrm{g} \mathrm{gm}^{-1}$ $\mathrm{Cd}, 31,532 \mu \mathrm{g} \mathrm{gm}^{-1}-\mathrm{Pb}$ and 33,325 $\mu \mathrm{g} \mathrm{gm}^{-1}$ $-\mathrm{Zn}$ at higher concentration- $50 \mathrm{ppm}$. Similarly, the uptake of metal in shoots was found to be $1,513 \mu \mathrm{g} \mathrm{gm}^{-1} \mathrm{Cd}, 1,366 \mu \mathrm{g} \mathrm{gm}^{-1}$ $\mathrm{Pb}$ and $1,889 \mu \mathrm{g} \mathrm{gm}^{-1} \mathrm{Zn}$ at lower doses (5 ppm); whereas uptake increased to $7,657 \mu \mathrm{g}$ $\mathrm{gm}^{-1} \mathrm{Cd}, 12,775 \mu \mathrm{g} \mathrm{gm}^{-1} \mathrm{~Pb}$ and 15,940 $\mu \mathrm{g}$ $\mathrm{gm}^{-1} \mathrm{Zn}$ at higher level exposures of metal (50 ppm). Cd was found 3.86 times more in roots as compared to shoots at $50 \mathrm{ppm} \mathrm{Cd}$ level. $\mathrm{Pb}$ and $\mathrm{Zn}$ were found 2.46 and 2.1 times more in roots than shoots at the higher exposure concentration, i.e. 50ppm.

The present research work indicates that $H$. annuus with high biomass has efficiently removed $\mathrm{Cd}, \mathrm{Pb}$ and $\mathrm{Zn}$ from aquatic environment and can be considered as a suitable potential plant for decontamination of heavy metals.

\section{Phytoremediation of Heavy Metals in Mycorrhizosphere}

The research work carried out for phytoremediation of heavy metals by Brassica juncea in mycorrhizal soil. Phytoremediation of cadmium, lead and zinc 
at varying concentrations viz. $0,5,10,20$ and $50 \mathrm{ppm}$ using $B$. juncea in the mycorrhizospheric soil for a period of two and half months has been studied.

\section{Dry biomass analysis}

The biomass results after 10 weeks of experiments indicated that the mean plant biomass of sunflower showed increasing tendency as the concentrations increased from 5 to $20 \mathrm{ppm}$ for $\mathrm{Cd}$ and $\mathrm{Pb}$ (Table 2). Biomass of plant was found to be $0.068 \mathrm{~g}$ in roots and $0.650 \mathrm{~g}$ in shoots for $\mathrm{Cd}, 0.065 \mathrm{~g}$ in roots and $0.705 \mathrm{~g}$ in shoots for $\mathrm{Pb}$ and 0.090 $\mathrm{g}$ in roots and $0.997 \mathrm{~g}$ in shoots for $\mathrm{Zn}$ at 50 ppm concentration at the end of pot culture experiment. Biomass decreased gradually as the concentration of $\mathrm{Cd}$ and $\mathrm{Pb}$ in the mycorrhizal soil media increased from 20 ppm to $50 \mathrm{ppm}$. The plant growth was affected at the higher ppm levels of $\mathrm{Cd}$ and $\mathrm{Pb}$, resulting into reduction in the biomass. A significant positive effect seen in $\mathrm{Zn}$ concentrations exposure (lower to higher concentrations) causing increased biomass with increasing exposure of $\mathrm{Zn}$ levels in mycorrhizosphere. The results showed an increasing tendency for biomass production $(\mathrm{Cd}$ and $\mathrm{Pb})$ as the concentrations increased from 5 to $10 \mathrm{mg} / \mathrm{kg}$. The positive effects have been seen in case of $\mathrm{Zn}$ concentrations. However, the biomass yield was found only affected at the higher concentrations, i.e. 20 and $50 \mathrm{mg} / \mathrm{kg}$ of $\mathrm{Cd}$ and $\mathrm{Pb}$ that shows inhibitory effect on plant growth. In our research, AM symbiosis enhances plant biomass via 'Metal- Binding' by decreasing HM bioavailability and subsequently reducing potential phytotoxic effects. Although it is well known that the enhanced uptake of any limiting elements usually enhances plant growth (Kothari et al., 1990; Marschner, 1995). The present research proved that mycorrhizosphere has positive effect on plant growth and heavy metal uptake by $H$. annuus. Similar to our study,
Patrick and Charest (2007), also illustrated the important compromise between plant growth, plant heavy metal uptake and tolerance, and further emphasized the importance of arbuscular mycorrhizae symbiosis in buffering the soil environment for plants under such stress conditions.

\section{Bioaccumulation of metals in the roots and shoots of plants}

The mean uptake of all three metals by sunflower plants increased as the concentration of these metals in mycorrhizal soil increased (Fig. 3). In this plant the heavy metals, $\mathrm{Cd}, \mathrm{Pb}$ and $\mathrm{Zn}$ were uptaken by shoots and roots both. $\mathrm{Pb}$ concentration was found to be higher in roots than $\mathrm{Cd}$. The uptake of $\mathrm{Cd}$ from mycorrhizosphere by $H$. annuus has shown to be $2,150 \mu \mathrm{g} \mathrm{gm}^{-1}$ and $35,600 \mu \mathrm{g} \mathrm{gm}^{-1}$ at 5 and $50 \mathrm{ppm}$ in roots and $1,471 \mu \mathrm{g} \mathrm{gm}^{-1}$ and $8,194 \mu \mathrm{g} \mathrm{gm}^{-1}$ at 5 and 50 ppm in shoots. The $\mathrm{Pb}$ uptake was 3,227 and $32,473 \mu \mathrm{g} \mathrm{gm}^{-1}$ at 5 and $50 \mathrm{ppm}$, respectively in roots and $1,188 \mu \mathrm{g} \mathrm{gm}^{-1}$ at $5 \mathrm{ppm}$ and $16,227 \mu \mathrm{g} \mathrm{gm}^{-1}$ at $50 \mathrm{ppm}$ in shoots. $\mathrm{Zn}$ uptake was again found highest in $H$. annuus and found 3,869 $\mathrm{gg} \mathrm{gm}^{-1}$ in roots and 34,535 $\mu \mathrm{g} \mathrm{gm}^{-1}$ in shoot. The heavy metals were uptaken by the sunflower plants in the order: $\mathrm{Zn}>\mathrm{Cd}>\mathrm{Pb}$.

Heavy metals: $\mathrm{Cd}, \mathrm{Pb}$ and $\mathrm{Zn}$ accumulation in roots and shoots of the plant- $H$. annuus was compared and shown Fig. 5.28. The metal uptake in roots was found $2150 \mu \mathrm{g} \mathrm{gm}^{-}$ ${ }^{1}(\mathrm{Cd}), 3227 \mu \mathrm{g} \mathrm{gm}^{-1}(\mathrm{~Pb})$ and $3869 \mu \mathrm{g} \mathrm{gm}^{-1}$ (Zn) at lower doses $(5 \mathrm{ppm})$. The uptake of metals in roots was increased upto $35,600 \mu \mathrm{g}$

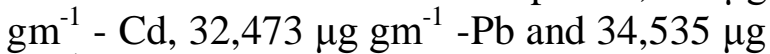
$\mathrm{gm}^{-1}-\mathrm{Zn}$ at higher concentration- $50 \mathrm{ppm}$. Similarly, the uptake of metal in shoots was found to be $1,471 \mu \mathrm{g} \mathrm{gm}^{-1} \mathrm{Cd}, 1,042 \mu \mathrm{g} \mathrm{gm}^{-1}$ $\mathrm{Pb}$ and $1,188 \mu \mathrm{g} \mathrm{gm}^{-1} \mathrm{Zn}$ at lower doses (5 ppm); whereas uptake increased to $8,194 \mu \mathrm{g}$ $\mathrm{gm}^{-1} \mathrm{Cd}, 16,227 \mu \mathrm{g} \mathrm{gm}^{-1} \mathrm{~Pb}$ and 19,040 $\mu \mathrm{g}$ $\mathrm{gm}^{-1} \mathrm{Zn}$ at higher doses (50 ppm). 
Table.1 Dry biomass of $H$. annuus after 21 days of exposure to the heavy metals contaminated Hoagland solution. $\dagger$

\begin{tabular}{|l|l|l|l|}
\hline Metal & $\begin{array}{l}\text { Concentration } \\
\left(\boldsymbol{\mu} \mathbf{~ m l}^{-1}\right)\end{array}$ & $\begin{array}{c}\text { Dry Weight }(\mathbf{g}) \\
\text { Roots }\end{array}$ & \multicolumn{1}{c|}{ Shoots } \\
\hline $\mathrm{Zn}$ & Control & $0.085 \pm 0.001$ & $0.661 \pm 0.052$ \\
\hline & 5 & $0.089 \pm 0.004$ & $0.784 \pm 0.039$ \\
\hline & 10 & $0.076 \pm 0.005$ & $0.648 \pm 0.045$ \\
\hline & 20 & $0.058 \pm 0.004$ & $0.564 \pm 0.025$ \\
\hline & 50 & $0.042 \pm 0.005$ & $0.451 \pm 0.027$ \\
\hline $\mathrm{Cd}$ & Control & $0.032 \pm 0.010$ & $0.160 \pm 0.006$ \\
\hline & 5 & $0.038 \pm 0.006$ & $0.166 \pm 0.005$ \\
\hline & 10 & $0.034 \pm 0.004$ & $0.161 \pm 0.006$ \\
\hline & 20 & $0.023 \pm 0.004$ & $0.114 \pm 0.004$ \\
\hline $\mathrm{Pb}$ & 50 & $0.014 \pm 0.001$ & $0.076 \pm 0.007$ \\
\hline & Control & $0.061 \pm 0.004$ & $0.416 \pm 0.018$ \\
\hline & 5 & $0.066 \pm 0.004$ & $0.422 \pm 0.010$ \\
\hline & 10 & $0.053 \pm 0.003$ & $0.386 \pm 0.015$ \\
\hline & 20 & $0.044 \pm 0.002$ & $0.289 \pm 0.007$ \\
\hline & 50 & $0.021 \pm 0.005$ & $0.222 \pm 0.033$ \\
\hline
\end{tabular}

$\uparrow$ Values are averages of three replicates + S.D.

Table.2 Dry biomass of $H$. annuus after two and half months exposure to the mycorrhizal soil enriched with heavy metals. $\dagger$

\begin{tabular}{|l|l|l|l|}
\hline Metal & $\begin{array}{l}\text { Concentration } \\
(\mathrm{mg} / \mathrm{kg})\end{array}$ & $\begin{array}{l}\text { Dry Weight }(\mathrm{g}) \\
\text { Roots }\end{array}$ & \multicolumn{1}{|c|}{ Shoots } \\
\hline $\mathrm{Zn}$ & Control & $0.075 \pm 0.002$ & $0.712 \pm 0.020$ \\
\hline & 5 & $0.082 \pm 0.003$ & $0.850 \pm 0.033$ \\
\hline & 10 & $0.093 \pm 0.004$ & $0.923 \pm 0.027$ \\
\hline & 20 & $0.091 \pm 0.003$ & $0.952 \pm 0.034$ \\
\hline & 50 & $0.090 \pm 0.001$ & $0.997 \pm 0.030$ \\
\hline $\mathrm{Cd}$ & Control & $0.075 \pm 0.002$ & $0.712 \pm 0.020$ \\
\hline & 5 & $0.086 \pm 0.002$ & $0.832 \pm 0.029$ \\
\hline & 10 & $0.099 \pm 0.005$ & $0.906 \pm 0.042$ \\
\hline & 20 & $0.082 \pm 0.007$ & $0.770 \pm 0.018$ \\
\hline & 50 & $0.068 \pm 0.008$ & $0.650 \pm 0.036$ \\
\hline $\mathrm{Pb}$ & Control & $0.075 \pm 0.002$ & $0.712 \pm 0.020$ \\
\hline & 5 & $0.079 \pm 0.003$ & $0.722 \pm 0.018$ \\
\hline & 10 & $0.085 \pm 0.002$ & $0.821 \pm 0.025$ \\
\hline & 20 & $0.080 \pm 0.002$ & $0.852 \pm 0.023$ \\
\hline & 50 & $0.065 \pm 0.004$ & $0.705 \pm 0.037$ \\
\hline
\end{tabular}

$\dagger$ Values are averages of three replicates + S.D. 
Fig.1 (a) $\mathrm{Cd}$, (b) $\mathrm{Pb}$ and (c) $\mathrm{Zn}$ depletion from the solution during phytoremediation experiments. The results show the depletion at various concentrations of $\mathrm{Cd}, \mathrm{Pb}$ and $\mathrm{Zn}$. All the values are mean of three replicates

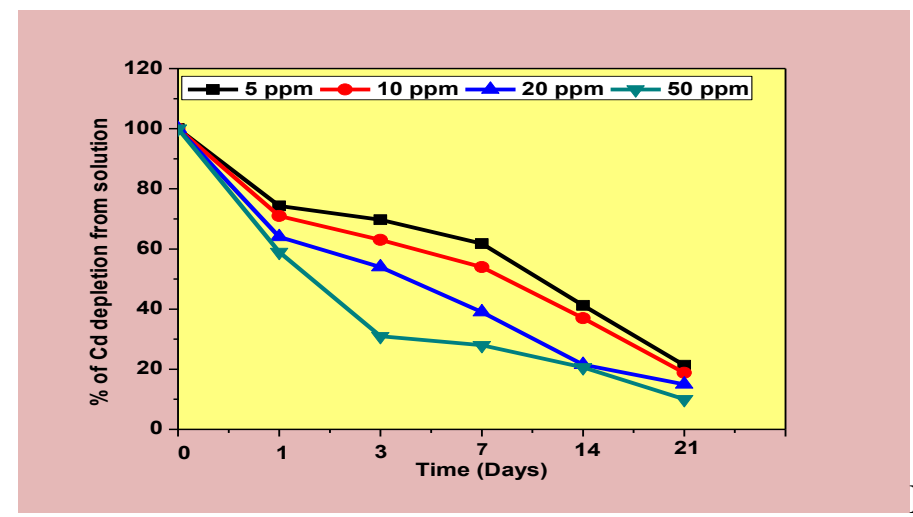

Fig. 1a

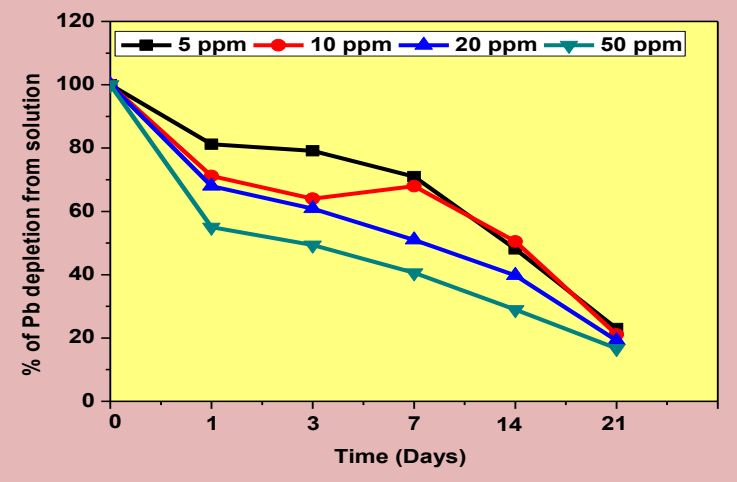

Fig. $1 b$

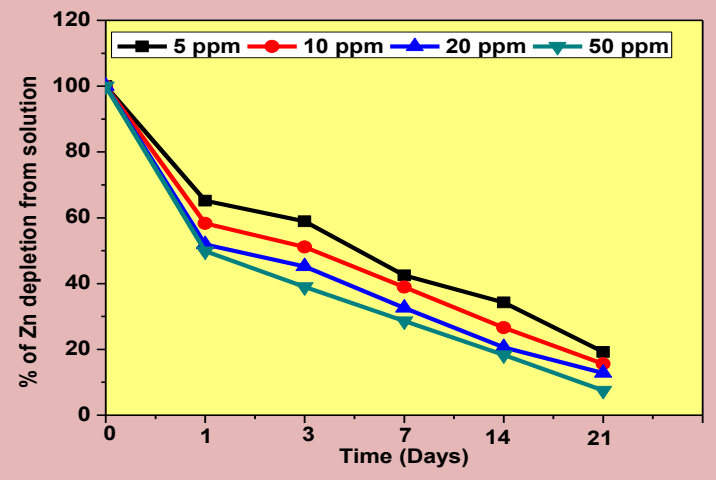

Fig. 1c 
Fig.2 Accumulation of $\mathrm{Cd}[\mathrm{A}], \mathrm{Pb}[\mathrm{B}]$ and $\mathrm{Zn}[\mathrm{C}]$ in the roots and shoots of H. annuus
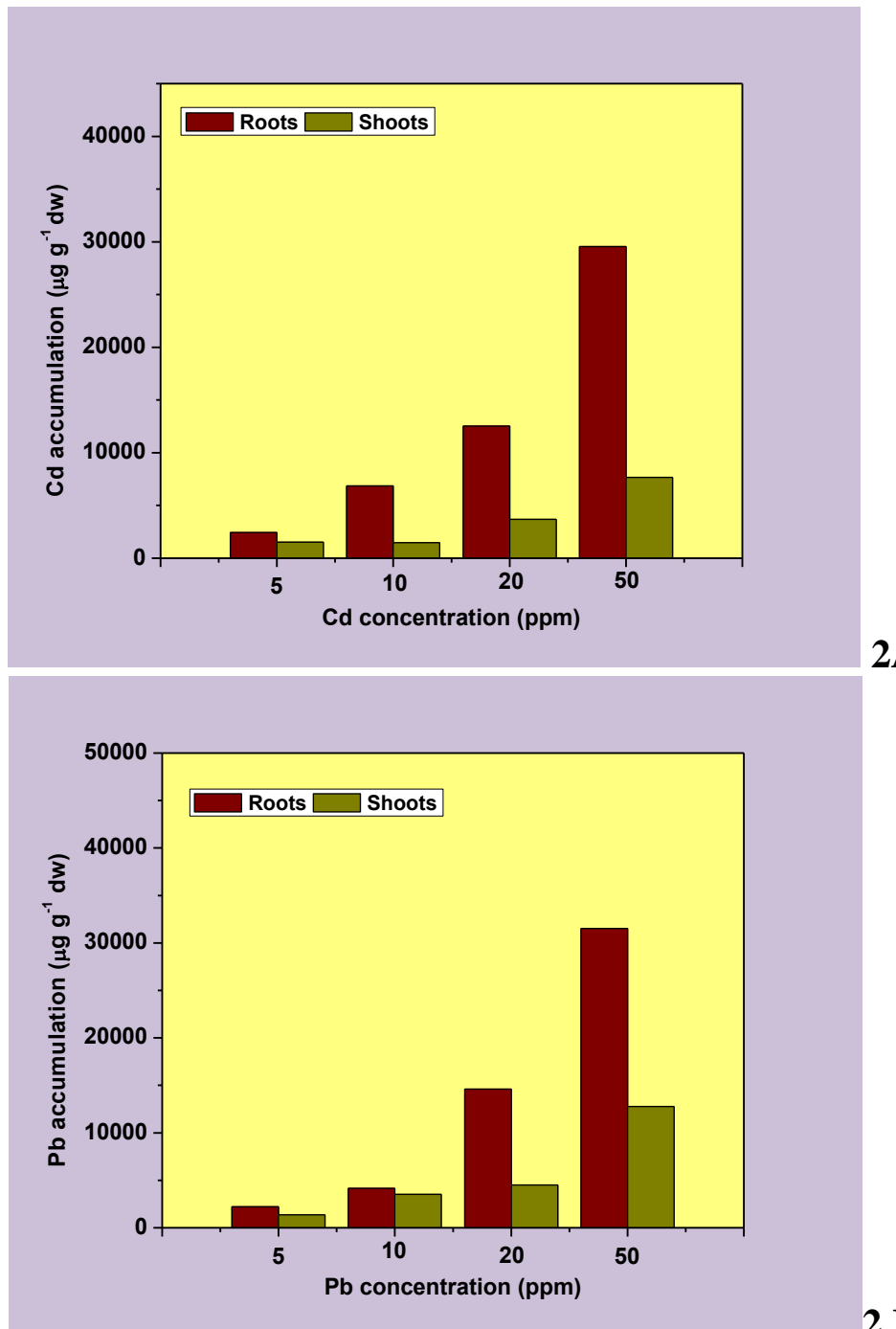

A

2 B

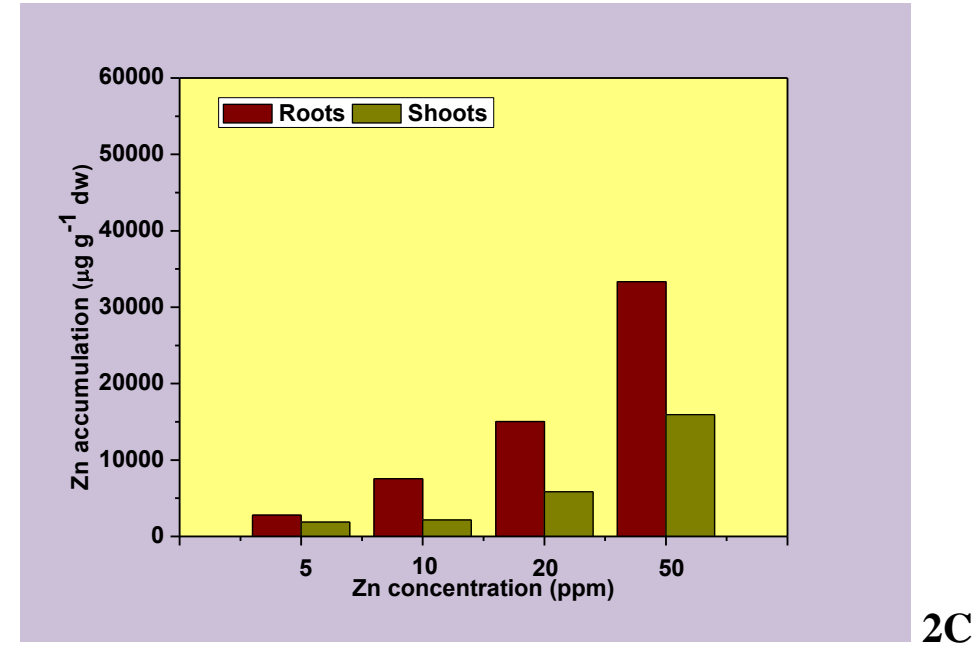


Fig.3 $\mathrm{Cd}[\mathrm{A}] \mathrm{Pb}[\mathrm{B}]$ and $\mathrm{Zn}[\mathrm{C}]$ accumulation in the roots and shoots of $H$. annuus during metal remediation from mycorrhizosphere soil
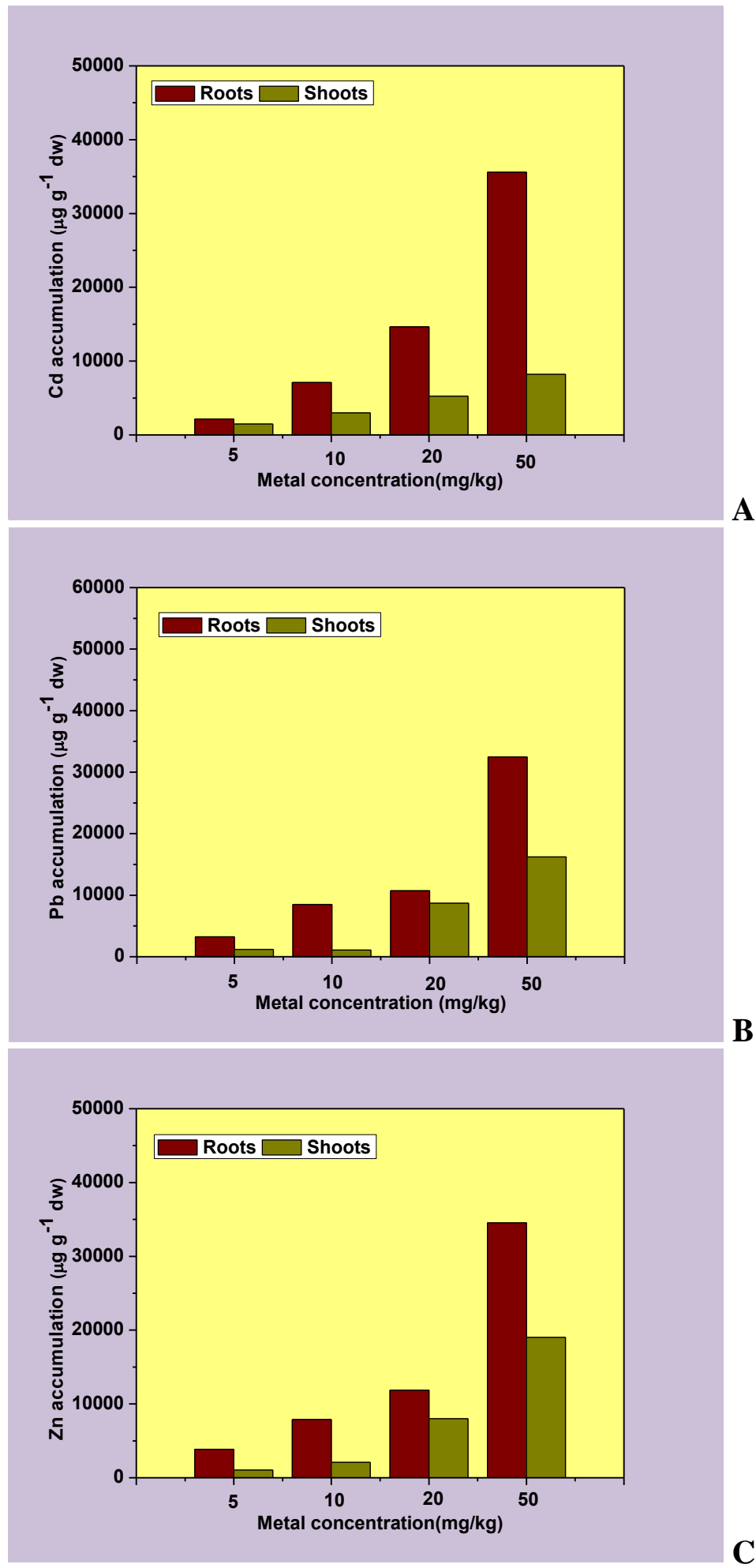
The comparison of data analysis shows that heavy metals studied were accumulated more in roots followed by shoots of $H$. annuus. $\mathrm{Cd}$ was found 4.34 times more in roots as compared to shoots at $50 \mathrm{ppm} \mathrm{Cd}$ level. $\mathrm{Pb}$ and $\mathrm{Zn}$ were found 2 and 1.81 times more in roots than shoots at the higher exposure concentration, i.e. $50 \mathrm{ppm}$ in mycorrhizosphere.

In the present research study, the role of AM symbiosis on relative plant biomass as influenced by the soil- heavy metal bioavailability and uptake of heavy metal by $H$. annuus has been reported. The results showed that $H$. annuus significantly bioaccumulated heavy metals at the varying concentrations ranging from 5, 10, 20 and 50 $\mathrm{mg} / \mathrm{kg}$. The uptake of heavy metals was found to be increased with increasing concentration of metals in the mycorrhizosphere (Fig.3). The results are in accordance with Giasson et al. (2006), where he proved that AMF can play a role in the phytoremediation of heavy metalcontaminated soil (Mycorrhizo remediation), by colonizing the roots, increases plant growth by making soil essential elements like zinc and phosphorus more accessible.

An increasing trend of accumulation in $H$. annuus was observed with increase in metal concentration in mycorrhizosphere. The accumulation of $\mathrm{Cd}, \mathrm{Pb}$ and $\mathrm{Zn}$ was reported more in root than the shoot. The present research demonstrated that mycorrhizal fungi could protect plants growth in metal contaminated soils by enhancing metal retention in roots and reducing metal partition to shoots (Leyval, et al., 2002). Researchers have reported that there is direct evidence for the strong binding capacity of fungal mycelium to heavy metals, such as $\mathrm{Zn}$ and $\mathrm{Cd}$ (Chen et al., 2001; Joner et al., 2000). Zinc being micronutrient found translocated proportionately in root and shoot. However, $\mathrm{Cd}$ and $\mathrm{Pb}$ accumulation in the root and shoot was found less as compared to $\mathrm{Zn}$ in $H$. annuus.

The increased quantity of organic matter in mycorrhizal soil could effectively increase the activity of metals in soil and improve metal mobility and distribution in soil. The application of natural fertilizer (vesicular arbuscular mycorrhiza) in soils has helped in increase in metal mobility through the formation of soluble metal organic complexes. In addition, exudation of organic compounds by plant roots, such as organic acids, influence ion solubility and uptake through their effects on microbial activity, rhizosphere physical properties, and rootgrowth dynamics (Klassen et al., 2000).

Mycorrhizal hyphae cause the aggregation of the soil particles, which increase the rate of movement of water and nutrients from the bulk soil to the root surface (Filion et al., 1999; Hooker and Black, 1995; George et al., 1995).

This environment is favourable for the flourish of microbes, which influence the mycorrhizal uptake of water and nutrients. The microbial interaction in the mycorrhizosphere involves a number of bacteria and fungi that influence plant growth (Hampp et al., 2000). Mycorrhizae due to their role in nutrient cycling, keep more nutrient in the biomass and in doing so increase the productivity which helps in proper growth and development of plants in turn results in maximum accumulation of heavy metals.

In conclusion, the green plant $H$. annuus has been identified as potential candidate for remediation of heavy metals - $\mathrm{Cd}, \mathrm{Pb}$ and $\mathrm{Zn}$ from aquatic/ terrestrial environment. Phytoremediation of heavy metals by $H$. annuus shows that the plants have 
remediated $79-90 \% \mathrm{Cd}, 77-89 \% \mathrm{~Pb}$ and $81-$ $92 \% \mathrm{Zn}$ at $5-50 \mathrm{ppm}$ concentrations from the aquatic environment. $H$. annuus has been found to have high biomass at varying exposure concentrations which resulted in increased uptake of heavy metals. Bioaccumulation of these metals in plant increased significantly with increasing metal concentrations. Maximum levels of zinc, cadmium and lead were observed in roots followed by shoots. This shows that $H$. annuus has tolerance potential to grow in contaminated environment and found efficient to take up heavy metals. The present research work indicates that $H$. annuus with high biomass has efficiently removed cadmium, lead and zinc from aquatic environment and proved a suitable potential plant for decontamination of heavy metals polluted environment.

\section{References}

Anamika, S., Eapen, S., Fulekar, M.H. (2009). Potential of Medicago sativa for uptake of cadmium from contaminated environment. Romanian Biotechnol. Lett., 14(1): 4164-4169.

APHA, AWWA, WEF. 1998. Standard Methods for the Examination of Water and Wastewater. The Association, Washington DC.

Aslan, M., Ünlü, M.Y., Türkmen, N., Yilmaz, Y.Z. 2003. Sorption of cadmium and effects on growth, protein content and photosynthetic pigment composition of Nasturtium officinale $\mathrm{R}$. Br. and Mentha aquatica L. Bull. Environ. Contamination and Toxicol., 71: 323-329.

Boonyapookana, B., Parkpian, P., Techapinyawat, S., Delaune, R.D., Jugsujinda, A. 2005. Phytoaccumulation of lead by Sunflower (Helianthus annuus), Tobacco (Nicotiana tabacum) and Vetiver (Vetiveria zizanioides). J. Environ.
Sci. Health, 40: 117-137.

Chen, B., Christie, P., Li, X. 2001. A modified glass bead compartment cultivation system for studies on nutrient and trace metal uptake by arbuscular mycorrhiza. Chemosphere, 42; 185-192.

Ernst, W.H.O., Verkleji, J.A.C., Schat, H. 1992. Metal tolerance in plants. Acta Botanica Neerlandica, 41, 229-248.

Filion, M., St.Arnaud, M., Fortin, J.A. 1999. Direct interaction between the arbuscular mycorrhizal fungus Glomus intraradices and different rhizosphere microorganisms. New Phytologist, 141: 525-533.

George, E., Marschner, H., Jakobsen, I. 1995. Role of arbuscuilar mycorrhizal fungi in uptake of phosphorus and nitrogen from soil. Critical Review in Biotechnol., 15: 257-270.

Giasson, P., Jaouich, A., Cayer, P., Gagné, S., Moutoglis, P., Massicotte, L. 2006. Enhanced phytoremediation: A study of mycorrhizoremediation of heavy metal-contaminated soil. Remediation $J .$, 17(1): $97-110$.

Hampp, R., Nehls, U., Wallenda, T. 2000. Physiology of mycorrhiza. In: K.Esser, J.W.Kadereit, U.Lütter and M. Runge (eds.) Progress in Botany. Genetics, Physiology, Systemates, Ecol., 61: 223-254.

Hoagland, D.R. and Arnon, D.I. 1938. The water culture method for growing plants without soil. Calif. Agri. Exp. Station Circ., 3: 346-347.

Hooker, J.E. and Black, K.E. 1995. Arbuscular mycorrhizal fungi as a component of sustainable soil plant systems. Critical Review in Biotechnol., 15: 201-212.

Joner, E.J., Briones, R., Leyval, C. 2000. Metal binding capacity of arbuscular mycorrhizal mycelium. Plant Soil, 226, 227-234. 
Kayser A., Schroder T.J., Grunwald A., Schulin R. 2001. Solubilization and plant uptake of zinc and cadmium from soils treated with elemental sulfur, Int. J. Phytoremediation, 3: 381-400.

Klassen, S.P., McLean, J.E., Grossel, P.R., Sims, R.C. 2000. Fate and behavior of lead in soils planted with metal resistant species (River birch and smallwing sedge), J. Environ. Quality, 29: 1826-1834.

Kothari, S.K., Marschner, H., Romheld, V. 1990. Contribution of the VA mycorrhizal hyphae in acquisition of phosphorus and zinc by maize grown in a calcareous soil. Plant and Soil, 131: 177-185.

Leyval, C., Joner, E. J., del Val, C., Haselwandter, K. 2002. Potential of arbuscular mycorrhizal fungi for bioremediation. Mycorrhizal Technology in Agriculture. Ed. By S. Gianinazzi, H. Schuepp, J.M. Barea K. Haselwandter. Birkhauser Verlag/ Switzerland.

Leyval, C., Turnau, K., Haselwandter, K. 1997. Effect of heavy metal pollution on mycorrhizal colonization and function: physiological, ecological and applied aspects. Mycorrhiza, 7: 139153.

Mahajan, B.K. 1997. Methods in Biostatistics for medical students and research workers, $6^{\text {th }}$ Edition, New Delhi: Jaypee Brothers.

Marschner, H. 1995. Mineral nutrition of higher plants. Academic Press, San Diego. pp. 889.

Murashige, T. and Skoog, F. 1962. A revised medium for rapid growth and bioassays with tobacco tissue culture. Physiologia Plantarum, 15: 473-497.

Patrick, A. and Charest, C. 2007. Dynamics of arbuscular mycorrhizal symbiosis in heavy metal phytoremediation: Meta-analytical and conceptual perspectives. Environ. Pollu., 147: 609- 614.

Sinha, S., Saxena, R., Singh, S. 2003. Chromium-induced lipid peroxidation in the plants of Pistia stratiotes L.: role of antioxidants and antioxidant enzymes. Chemosphere, 58: 596-604.

Vidali, M. 2001. Bioremediation: An overview. Pure and Appl. Chem., 73: 1163-1172.

\section{How to cite this article:}

Fulekar, M.H., 2016. Phytoremediation of Heavy Metals by Helianthus annuus in Aquatic and Soil environment. Int.J.Curr.Microbiol.App.Sci. 5(7): 392-404. doi: http://dx.doi.org/10.20546/ijcmas.2016.507.043 